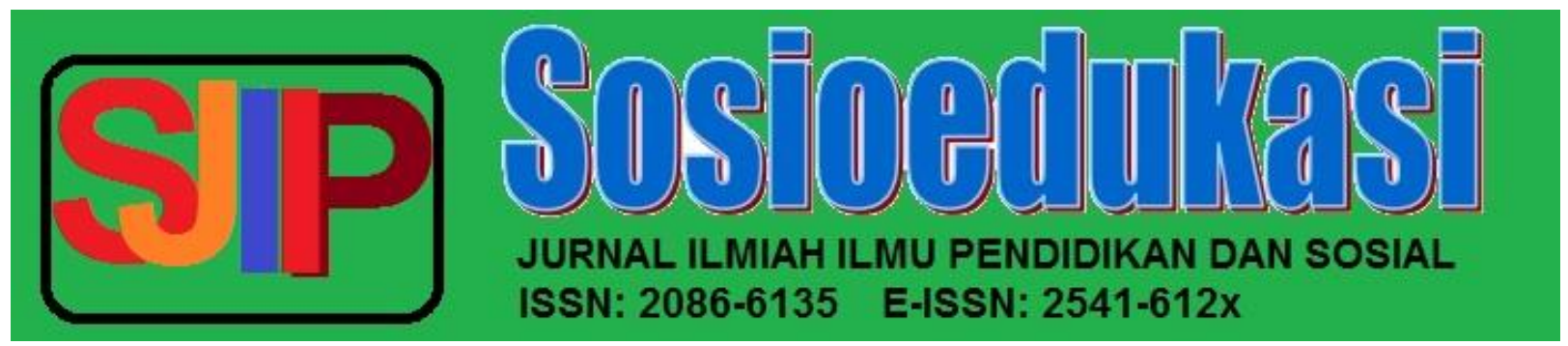

November Vol.9 No. 2 Tahun 2020 https://ejournal.unibabwi.ac.id/index.php/sosioedukasi/index

\title{
BUILDING CHARACTERS THROUGH 3P IMPLEMNTATION (APPEARANCE-SERVICE-ACHIEVEMENT)
}

\author{
M. Iqbal \\ SMA Negeri 2 Kota Tangerang Selatan \\ iqta.solo345@gmail.com
}

\section{ARTICLE HISTORY}

Received : 2310-2020

Revised : 18-10-2020

Accepted : 17-11-2020

\section{KEYWORDS}

Building Characters ; Through ;

3P Implemntation ;

\section{ABSTRACT}

Character education in a micro context, centered on a holistic education unit. Education unit is the main sector that optimally utilizes and empowers all existing learning environments to initiate, improve, strengthen, and continuously enhance the character education process in educational units. Education is what will make serious efforts and always be at the forefront of efforts to form the true character of Indonesian people. Character development is divided into four pillars, namely teaching and learning activities in class, daily activities in the form of cultural development of educational units; co-curricular and / or extra-curricular activities, as well as daily activities at home and in the community. In order to realize the goals of education in schools, effective management is required, with the aim of ensuring: 1) community access to adequate education services; 2) the quality and competitiveness of education and its relevance to the needs of society; and 3) effectiveness, efficiency and accountability of education management. Appearance, service, \& achievement (3P) are not new things in schools, but in fact there are still schools that do not pay attention to 3Ps properly. For example, there is still a school identity in the form of a school name board which is in a dull and rotten condition so that it cannot be read clearly \& cannot provide accurate information about the school. Another example, there are still schools that ignore cleanliness, safety, comfort \& beauty of the school environment such as yards, rooms (buildings) \& others. Likewise, the school's lack of attention to neatness, cleanliness \& harmony in the appearance and behavior shown by its residents.

According to Simon Philips, character is a collection of values that lead to a system, which underlies the thoughts, attitudes and behaviors that are displayed. Meanwhile, Doni Koesoema understands that character is the same as personality. Personality is considered as a characteristic, or characteristic, or style, or characteristic characteristic of a person that comes from formations received from the environment. In this sense the root of all evil and evil acts, evil acts, lies in the loss of character. Strong character is a fundamental view which gives the human population the ability to live together in peace and form a world filled with good and virtue, free from violence and immoral acts. 


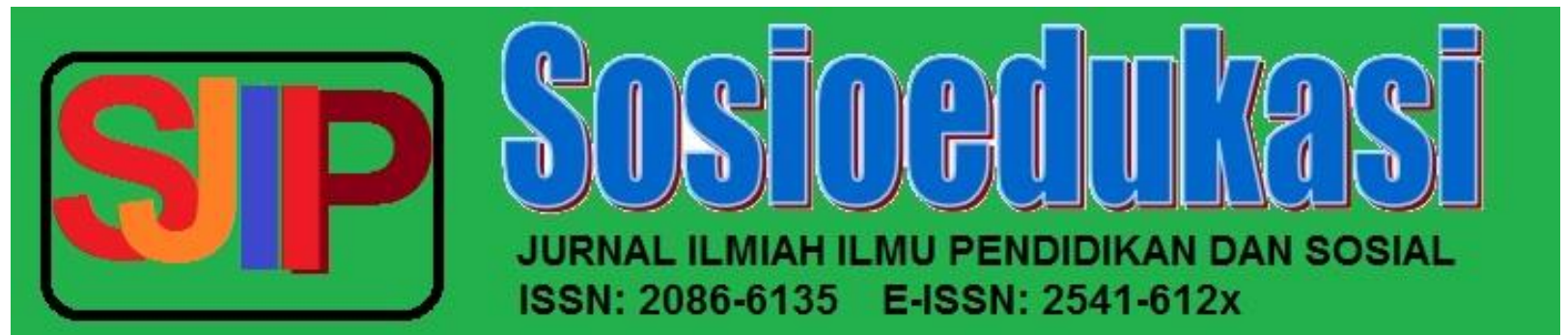

November Vol.9 No. 2 Tahun 2020 https://ejournal.unibabwi.ac.id/index.php/sosioedukasi/index

\section{INTRODUCTIONS}

\section{Background}

Character is not inherited, but something that is continually constructed day after day through thought and deed, thought for thought, action for action. Character is interpreted as a way of thinking and behaving that is unique to each individual to live and work together, both within the sphere of family, society, nation and state.

School management can be seen from performance school.Performance is an English word which means the result of a performance. According to Fattah (1999)performance can also be interpreted "as an expression of ability based on knowledge, attitudes, skills and motivation to produce something". Furthermore, Bernardin and Russel in Ahmad S Ruky (2001) state that "Performance is defined as the record of outcomes produced on a specified job function or activity during a specific time period".

The definition of performance above implies that performance is the result of a job or activity within a certain period of time, where each individual contributes to the institution, for example through the achievements he has achieved. In line with this opinion, Rawirosentoso (1999) states that: "performance is the work that can be achieved by a person or group of people in an organization in accordance with their respective authorities and responsibilities in order to achieve the goals of the organization concerned legally, does not violate the law and in accordance with morals and ethics ".

3P implementation is an effort to create an ideal school. The ideal school profile according to IAQ Design Tools For School, US EPA, 2011, is: 1) Healthy environment; 2) Physical buildings that are beautiful, clean, safe, and comfortable and provide adequate learning facilities; 3) A welcoming and friendly environment, both teachers, students, and other employees; 4) Carry out maximum service both inside and outside the school; 5) Have outstanding and proud achievements, academic and non-academic; 6) Communicating well with parents, and involving high levels of society. By paying attention to the importance of implementing appearance, service and school achievement, it is hoped that it will shape the character of the school community which at the same time can improve the school image.

\section{Problems}




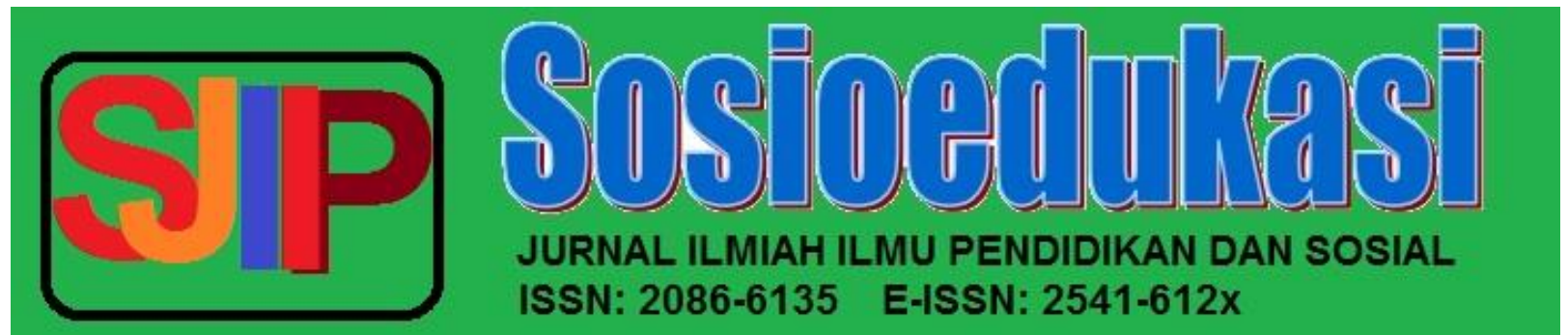

November Vol.9 No. 2 Tahun 2020 https://ejournal.unibabwi.ac.id/index.php/sosioedukasi/index

Appearance, service, \& achievement (3P) are not new in schools, but in fact there are still schools that do not pay attention to 3Ps properly. For example, there is still a school identity in the form of a school name board which is in a dull and rotten condition so that it cannot be read clearly $\&$ cannot provide accurate information about the school. Another example, there are still schools that ignore the cleanliness, safety, comfort \&

beauty of the school environment such as yards, rooms (buildings) \& others. Likewise, the school's lack of attention to neatness, cleanliness \& harmony in the appearance \& behavior shown by its residents.

\section{The Appearance}

physical appearance of the school is anything that is related to the appearance inside and outside the school which is easily observed and directly assessed, and can cause certain responses or responses from other people or the environment around them. The school's appearance that can be immediately observed includes a clean, safe, comfortable, beautiful, neat, and shady environment. A clean school means a school with "the environment is free of trash, not contaminated with dirt", smoke-free, and all residents apply 5S culture (smile, greeting, greeting, courtesy and courtesy). A safe school means a school that is "free from danger and distraction, protected, free from student brawl /bullying, and orderly, so that its citizens or outsiders do not" feel scared and worried ". While a comfortable school environment is a school that can make the situation of the "feel fresh, healthy, cool". A beautiful school does not mean luxury, but a school that looks good and is attractive, even though the school has a simple physique. Shady school is a beautiful school with an arrangement of plants that can shade the school environment.

The appearance of the school is a reflection of the self-image of the school which will become the character of the school community and is directly assessed by the community which must be addressed continuously by all school members. Appearance can be the main capital for schools as a selling point in society and parents. Appearance is also an important part related to shaping and enhancing a professional image as well as giving high self-confidence for all school members to express their respective potential

2. Services

Schoolare social institutions that have a service function for school residents, parents, and the community. Services in schools are efforts made by school residents through optimization of their duties and functions to create a conducive environment, including the provision of educational 


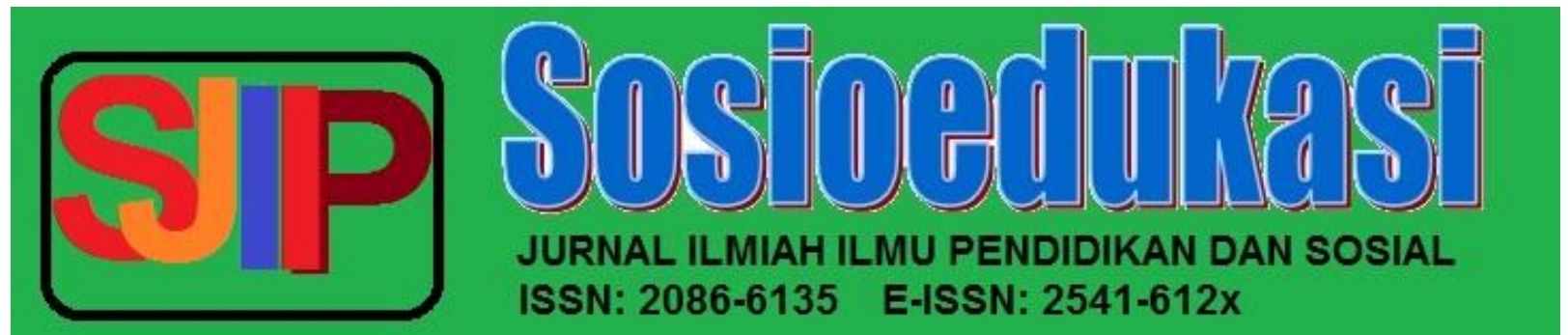

November Vol.9 No. 2 Tahun 2020 https://ejournal.unibabwi.ac.id/index.php/sosioedukasi/index

facilities, implementation of various programs and activities, and readiness of information and communication services.

a. School Citizen

Services Services must be carried out by educators and educational staff, as well as students according to their respective roles. Services can be provided in the form of providing accurate information about school data and programs that can promote school excellence and achievement. To do this, schools should have a special training program for excellent service, including work motivation and entrepreneurship for all its citizens.

b. Provision of Educational Facilities

To support the entire 3P program that has been implemented, schools have optimized the use and maintenance of infrastructure (rooms, furniture, tools and materials), as well as the implementation of the educational process by involving all school members.

c. Implementation of theProgram

Schoolimplements various programs for the benefit of developing the potential of students, both curricular and extracurricular programs, the implementation of which involves all citizens, in accordance with the activity plan in the School Activity Plan and Budget (RKAS).

d. Information and communication

services The school provides information and communication services that are easily accessible to school residents and the community, which are presented through data and information that are periodically refined according to developments.

3. Achievements.

Achievement is the result of a skill or concrete result from school members, both the achievement of students, educators and education personnel in the academic and non-academic fields. Achievements can be proven by trophies, medals, certificates, certificates, and so on. All evidence of achievement is well documented, organized and maintained, so that it can be used as a school promotion tool. To maintain and improve achievement, schools need to have programs and activities that support, for example programs superior student coaching.

\section{MATERIALS AND METHODS RESEARCH LOCATION}

This paper is written based on research using qualitative methods with the type of case study research that focuses more on program evaluation design. The author conducted in-depth and 


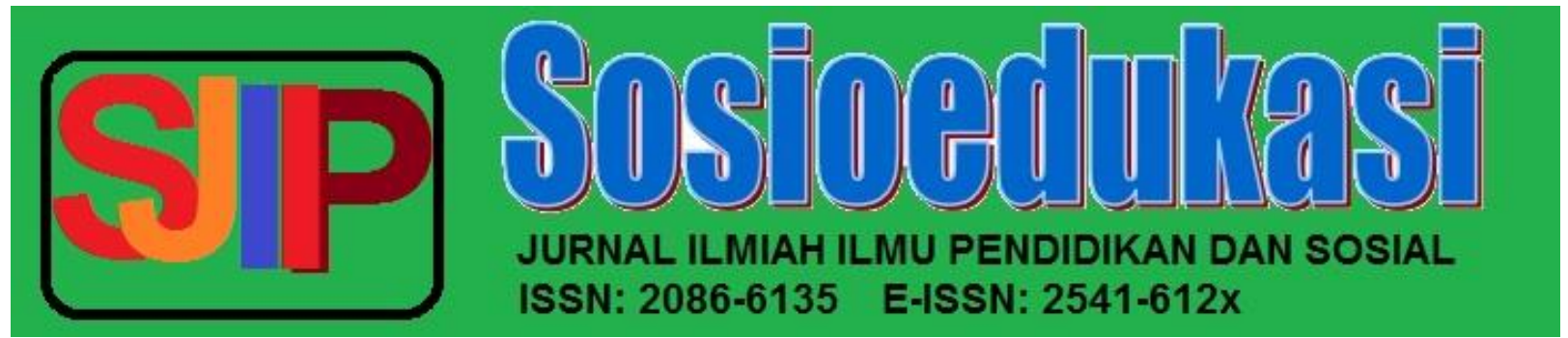

November Vol.9 No. 2 Tahun 2020 https://ejournal.unibabwi.ac.id/index.php/sosioedukasi/index

structured interviews with all elements of the SMA Negeri 2 Kota Tangerang Selatan. This subject search technique uses purposive sampling technique, (sampling technique is based on certain objectives). Because the samples were taken according to certain criteria to get a thorough understanding of the problems in this study. The criteria for determining informants in this study are based on evaluation of all elements in the school to improve the existing structure in it. Based on these criteria the researcher tries to select and narrow the informants in order to achieve the desired research objectives in this study. There were ten people interviewing researchers consisting of several educators and education staff, students and some school elements who assist in school activities. Researchers also use research instruments that support this research, including cameras and recording devices that can document any data obtained. From this data it will be processed and presented into a research report.

\section{RESULTS AND DISCUSSIONS}

The 3P implementation strategy is carried out comprehensively and is focused on the main tasks, functions and targets of each school member. To obtain maximum results, the 3P implementation strategy is implemented in an integrated manner by every school member who is supported synergistically by various parties. SMA includes planning, implementation, and evaluation. To implement 3P programs on target, complete data / information is required according to the needs analysis.

For the success of developing character through the implementation of $3 \mathrm{P}$ in schools, it is necessary to prepare preparation starting from planning, implementation, to evaluation.

\section{Planning}

3P planning can be done through the following steps:

a. Forming a work team that involves the deputy principal, teachers, education staff, school committees, and student council

b. The work team analyzes the strengths and weaknesses of the 3P aspects and indicators (part of the context analysis)

c. From the results of the analysis, it is determined the activities and targets that will be programmed to improve the image of the school through 3P which are arranged based on priority scale

d. Determine indicators of success, or targets to be achieved. 


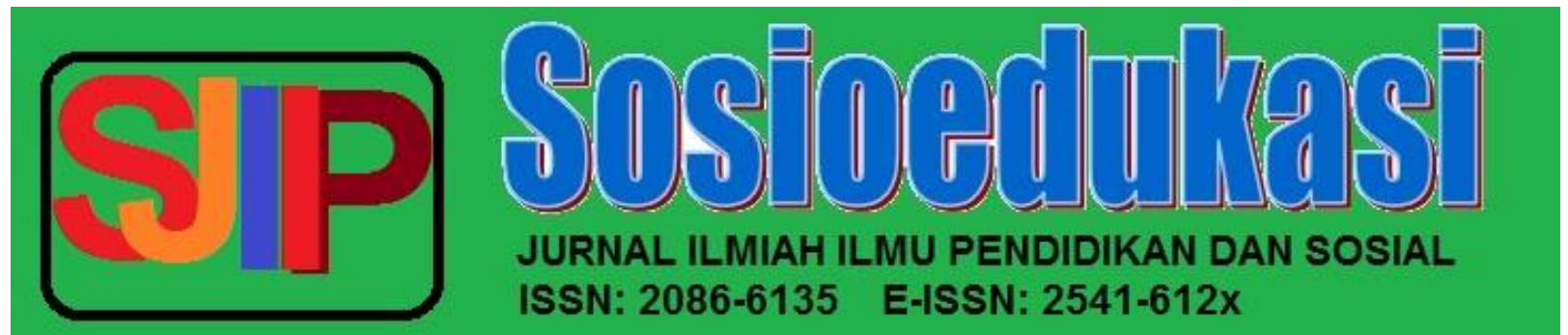

November Vol.9 No. 2 Tahun 2020 https://ejournal.unibabwi.ac.id/index.php/sosioedukasi/index

e. Determine the schedule of activities, based on priority scale.

f. Prepare the necessary Budget Plan (RAB). g. Develop a program / action plan that will be used as a reference in implementation.

\section{3PImplementation of the 3P}

implementationaction plan that has been determined, is carried out by involving all school members and committees according to their respective roles. In order for the $3 \mathrm{P}$ implementation to be carried out effectively and efficiently, it is necessary to have synergy between the activities, objectives and targets to be achieved by paying attention to the substance and personnel who will carry it out (who is doing what) among students, educators, and educational staff.

In this implementation, schools can apply principles, including:

1. Involving individuals or teams to participate in carrying out activities optimally, so as to create situations and conditions that motivate every school member.

2. The proper division of roles to encourage program implementation according to their duties and functions.

3. Appreciation for citizens' creative activity efforts that can be used as promotion for those concerned and school promotion.

The implementation of appearance, service and achievement (3P) is basically integrated into the school work plan which includes student programs, curriculum and learning activities, educators / education personnel and their development, facilities and infrastructure, finance and financing, school culture and environment, community participation and partnerships, and other work plans that lead to quality improvement and development. 3. Monitoring / Evaluation

Monitoring of 3P implementation is carried out through systematic and continuous observation to observe the $3 \mathrm{P}$ implementation that is being carried out in schools with reference to the principles of evaluation, namely continuous, comprehensive, objective, valid, critical and oriented towards usability and benefits 3P monitoring is also carried out for a certain period of time (for example every month), and refers to the action plans that have been set with the objectives of: 1) producing the best 3P implementation by obtaining feedback from all parties or aspects that the school is working on; 2) improving the work plan and taking immediate corrective actions for several activities that are not in accordance with the program; 3) explore progress and changes that have occurred in terms of input, process and output through a regular reporting and recording system; 4) 


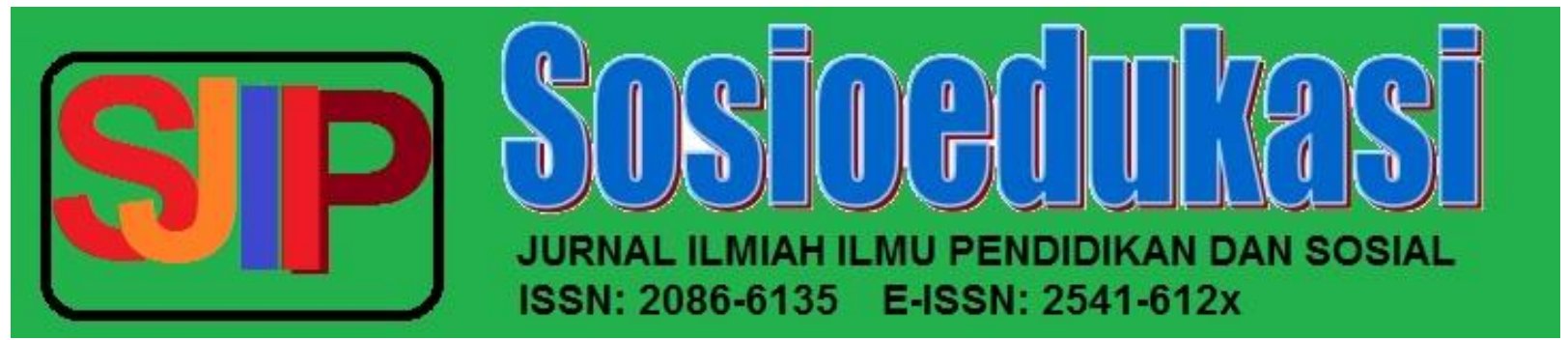

November Vol.9 No. 2 Tahun 2020 https://ejournal.unibabwi.ac.id/index.php/sosioedukasi/index

assisting decision makers, any matters that require full attention; 5) the findings of monitoring results will be used as material or part of the evaluation tool for further guidance.

The monitoring results are followed up with evaluation activities to determine the effectiveness, success, and feasibility of implementing 3P, so that schools can improve and develop the next program.

\section{Superior Program for 3p Implementation in Character The Development}

Superiorimplementation of $3 \mathrm{P}$ in an effort to build the character of school residents was developed to further optimize the habituation and character development of school residents. As the person in charge is the school principal, and technically this program is under the Principal of Student Affairs,

3p Cultural Program (Appearance, Service and Achievement) as an Effort to Build Student and School Character Character

\section{A. APPEARANCE}

a. The program to strengthen the implementation of student discipline through student discipline books, including:

- Socialization and application of rules for class X students starting from the implementation of the School Environment Introduction Period (MPLS) in theyear of 2016-2017 lessons to coaching by class X's homeroom teacher every month in the classroom each.

- Ordering and strengthening the implementation of discipline for class XII and class XI students from the beginning of the 2016-2017 school year centrally at GSG, coupled with motivation programs from motivators from external school parties invited by the school, to the implementation of coaching by class XII homerooms and homeroom teacher of class XI every month in their respective classes.

- Ordering and strengthening the implementation of student discipline in the classroom and in the school environment, including:

- aksanaan Implementation of the daily rules of students with the teachers of each subject in the classroom, and if there are deviations or violations of the rules, it is reported to the homeroom teacher. respectively, to be followed up with the counseling guidance teacher. 


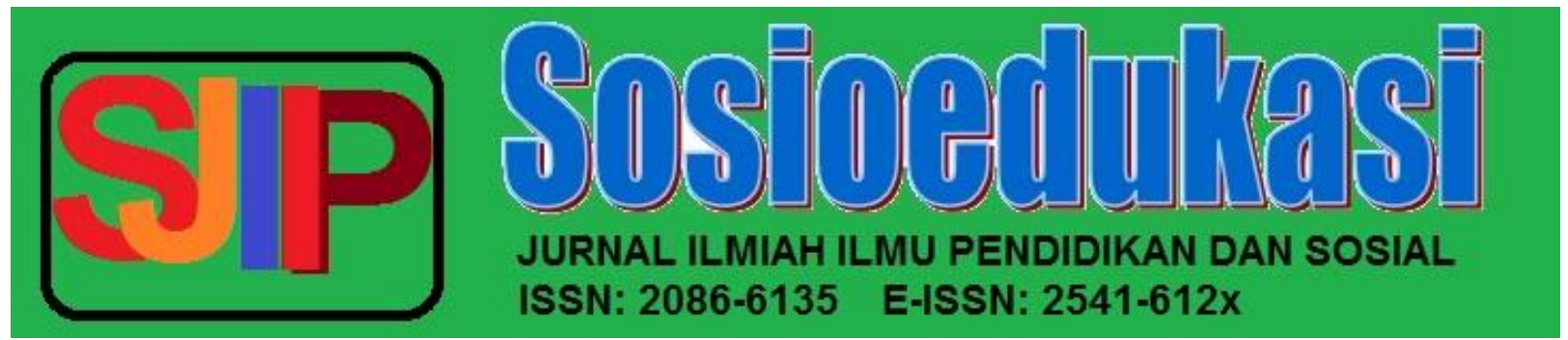

November Vol.9 No. 2 Tahun 2020 https://ejournal.unibabwi.ac.id/index.php/sosioedukasi/index

- Implementation of student discipline guidance through supervision of student discipline books by their respective homeroom teachers every month.

- Implementation of student discipline and other discipline through monthly case conferences with class teachers, counseling guidance and student field staff.

b. Controlling and carrying out unannounced inspections (sidak) with a team of teachers, including:

aksanaan The disciplinary action of students will be carried out suddenly simultaneously in the classroom and / or in designated places, involving other teachers. he technical for the sudden inspection (sidak) will be arranged in more detail with the 3P team

c. .Program for recording student discipline points, including:

- 8 This program for recording student discipline points will be carried out with the school's daily picket administration team with the IT team of SMA Negeri 2 Kota Tangerang Selatan. Reporting program to classmates. The results of the recording of the school's daily picket administration team will be reported regularly to the homeroom teacher as material for the case conference with the counseling guidance teacher team and the school principal's representative for student affairs.

- Student discipline points include student appearance in the morning when students arrive at the gate or school culture picket room - Student discipline points include student appearance in class with teaching teachers in class

- Student discipline points include appearance in the afternoon when the return of students with the teaching teacher at the last hour.

d. The best student awarding program for implementing student discipline, including:

terbaik Best student 3P (Tatib appearance) Odd Semester. Best student 3P (Tatib appearance) Odd Semester General Guidelines for School Culture Implementation:

a. The implementation of school culture is carried out by all school members in the SMA Negeri 2 Kota Tangerang Selatan.

b. School cultural activities include daily activities to control the completeness of student attributes (student appearance) according to the established student discipline book.

c. School cultural activities begin every day starting at 06.45 WIB (Monday, Tuesday and Thursday) and starting at 06.30 WIB (Wednesday and Friday) until the last teaching and learning activity schedule is in accordance with the predetermined lesson schedule. 


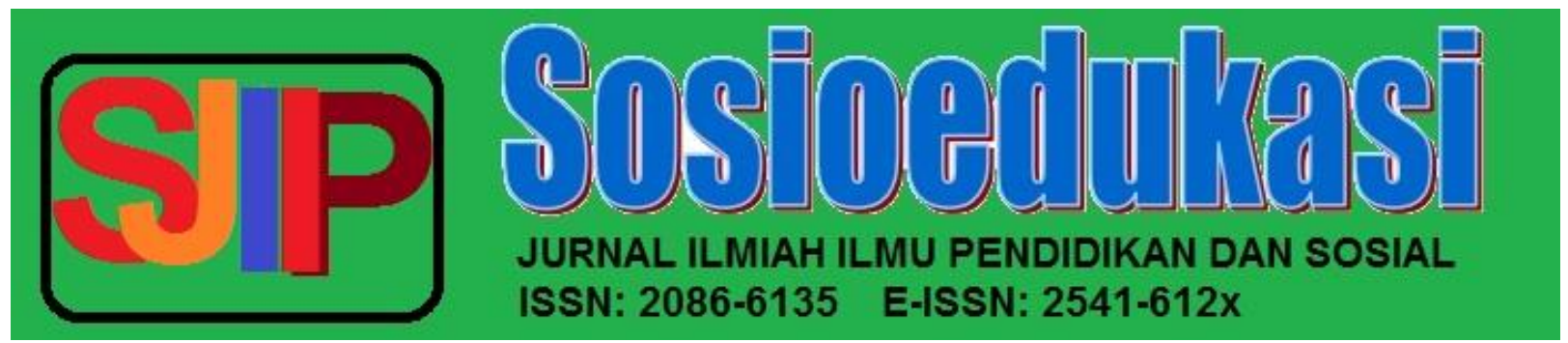

November Vol.9 No. 2 Tahun 2020 https://ejournal.unibabwi.ac.id/index.php/sosioedukasi/index

School cultural activities in the morning include:

- At 06.45 WIB the school culture team monitors the implementation of the 5S culture (Smile, Greetings, Greetings, Courtesy \& Courtesy) and order and tidiness of students at the school entrance (front office) and or at the point of assignment school daily picket.

- At 06.45 - 07.00 WIB the school culture team guided the implementation of group prayers centrally at the front office and appealed to all first hour teachers / homeroom teachers to accompany students in the classroom.

- At 07.00 - 07.05 WIB the school culture team guided the preparations for the implementation of singing the Indonesia Raya national anthem centrally at the front office and invited them to stand up to all school members simultaneously and simultaneously and sing thenational anthem Indonesia Raya together.

- At 7:05 to 7:10 pm school culture team invites all citizens to carry out further activities such as cultural activities of other schools, including:

1) Culture IMTAQ (Iman and Taqwa)

This team is responsible for the implementation of habituation to increase students' faith and devotion.

- For habituation, IMTAQ is scheduled every Wednesday and Friday starting at 06.30 WIB.

- Wednesdays in each class (reading their respective religious books) accompanied by the first hour teaching teacher.

- Fridays at the School Field.

2) Culture of GLS (School Literacy Movement)

This team is tasked with implementing thefond of reading.

1010 habit ofhabit The School Literacy Movement orof reading fondness is held every Tuesday and Thursday starting at $06.45-07.00$ WIB accompanied by a first hour teaching teacher / homeroom teacher. For other days set individually a minimum of 15 minutes to read books outside of school subjects that are liked and useful, such as fiction or biographies. 


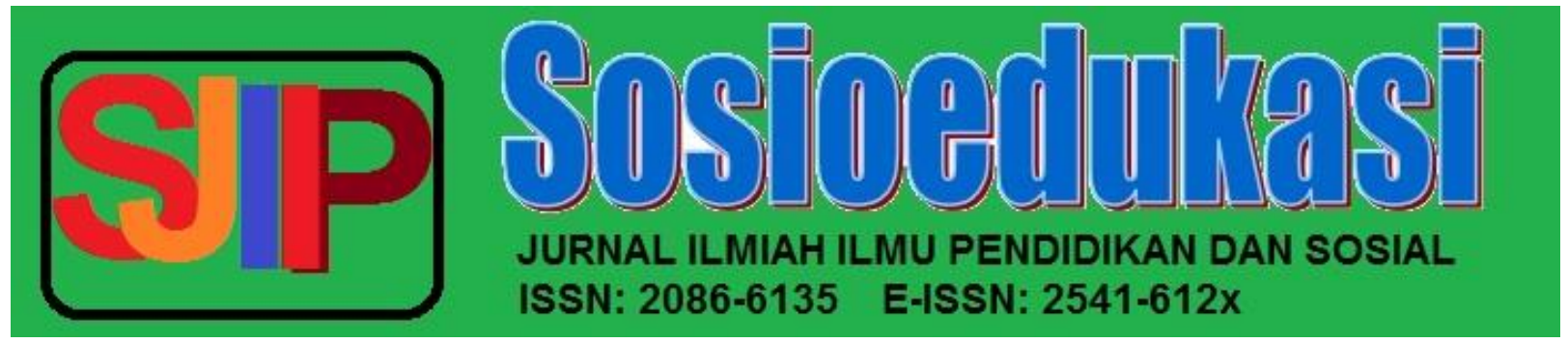

November Vol.9 No. 2 Tahun 2020 https://ejournal.unibabwi.ac.id/index.php/sosioedukasi/index

3) 3P Culture (Appearance, Service and Achievement) and Safe Schools This team is tasked with developing the implementation of school culture in the following aspects:

- Familiarizing students with obeying the existing rules in SMA Negeri 2 Tangerang Selatan, starting from the personal appearance of students to student discipline.

- Thehabits of disciplinarystudents will be gradually and periodically increased until order checks are made into the classroom environment and places that have been determined with the teacher team.

- The practice of implementing other daily school cultures, such as starting lessons, begins with praying and singing the Indonesia Raya national anthem together with the teacher at the first lesson and ending the lesson by singing regional songs or other national compulsory songs with the last hour lesson teacher.

4) SBLH Culture and Healthy Schools

This team is tasked with developing a clean and healthy lifestyle for school residents in the school environment.

The PHBS activities carried out by students include:

- Love Classroom Cleanliness (CKK)

- ClassAdipura

- Environmental Care Action (APL)

d. At $07.10-07.30$ WIB the organizer of the school culture picket on that day will reflect on the school culture activities on that day and record important events with other cultural teams

e. At 07.30 WIB the school culture picket team handed over activities at the front office to the daily picket teachers (BK teachers) and the school management team who had been appointed (Bpk. Sanin and Bpk Nediansyah) Special Guidelines for School Culture Implementation:

1. Implementation of the School Culture Team Picket The guidelines for the school culture team picket implementation include the following: 


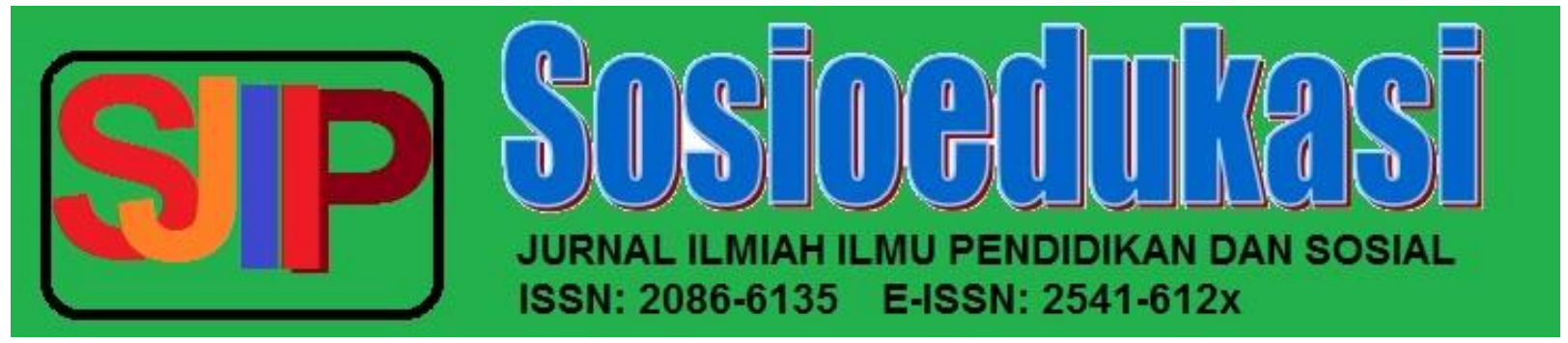

November Vol.9 No. 2 Tahun 2020 https://ejournal.unibabwi.ac.id/index.php/sosioedukasi/index

1) The school culture team picket implementer consists of the deputy principal and members of the school culture team, consisting of:

- IMTAQ cultural team (Faith and Taqwa)

- GLS Cultural Team ( School Literacy Movement)

- 3P Team (Service, Appearance, Achievement) and Safe Schools

- SBLH and Healthy School Teams whose implementation is regulated in the daily picket of the school culture team from Monday to Friday.

2) The implementation of the daily picket for the school culture team is at 06.15 - 15.30 WIB, according to the duties and distribution of the school culture picket posts.

3) In carrying out its duties, the School Culture Team is assisted by the daily picket team of teachers (BK teachers) and predetermined school administration.

4) As a daily picket administration officer, the school administration staff has been appointed by the School Principal Decree.

2. Implementation of school daily pickets (Counseling Guidance Teachers and School Administration Staff)

Instructions for implementing school daily pickets include the following:

1) School daily picket officers are counseling guidance teachers assisted by school administration staff who have been determined by the School Principal Decree.

2) As the administrator of school picket daily records, the school administration staff has been appointed in the School Principal Decree

3) The school picket daily registration team will record the daily rules of students in the point tatib program (software computerthat has been prepared by the school IT team ).

4) The recording of violations of the student's daily discipline is signed by the Counseling Guidance teacher on the knowledge of the School Culture Coordinator and the deputy principal on duty at that time. 


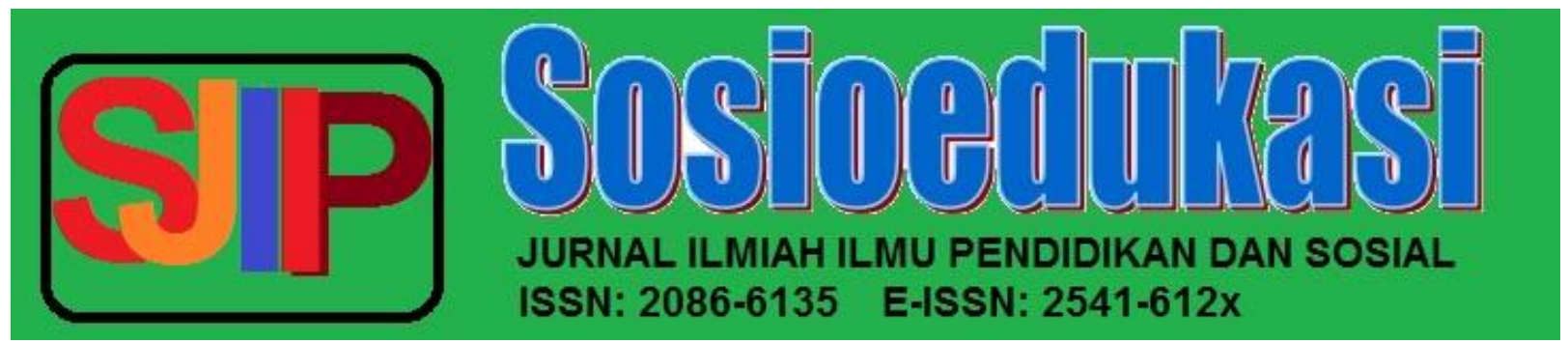

November Vol.9 No. 2 Tahun 2020 https://ejournal.unibabwi.ac.id/index.php/sosioedukasi/index

5) The school's daily picket recording administrator team will provide periodic reports (weekly, monthly reports) to those in need, especially in preparation for student case conferences which are held every month.

\section{B. SERVICES}

Services in schools are efforts made by school members through the optimization of their duties and functions to create a conducive environment, including the provision of educational facilities, implementation of various programs and activities, and readiness of information and communication services.

\section{CONCLUSIONS AND RECOMMENDATIONS}

\section{Conclusion}

School performance, service and achievement (3P) is not a program that is implemented for a moment, but is an activity of habituation and continuity. This requires effective management in planning, implementing, evaluating and developing programs by all school members.

according to their respective duties, functions and roles.

The successful implementation of 3P is built through the synergy of all school members, and 3P is related to complex targets between individuals, infrastructure, and the environment. The implementation of improving the image of the school through appearance, service and achievement (3P) in SMA is an effort for schools to:

1. Improve the physical appearance of facilities and school members;

2. Improving services for school residents through the capabilities they have;

3. Obtain and improve achievement in both academic and non-academic fields.

\section{Suggestions}

The success of 3P implementation is built on the synergy of all school members' performance, and 3Ps relate to complex targets between individuals, infrastructure, and the environment. Therefore, it is necessary to have an understanding of every school member in the substance of appearance, service and school performance which will be used as a reference in performance appraisal. Through monitoring and evaluation of the implementation of the 3Ps, schools can find out about the successes and problems of the school, so that the results can be used as feedback in improving and improving the program. 


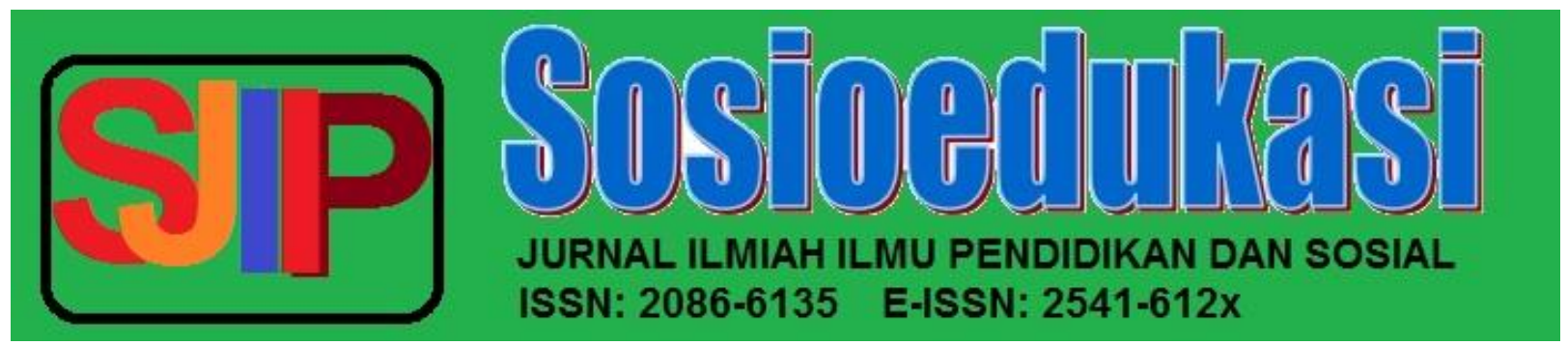

November Vol.9 No. 2 Tahun 2020 https://ejournal.unibabwi.ac.id/index.php/sosioedukasi/index

\section{REFERENCES}

Undang-Undang Nomor 20 Tahun 2003 tentang Sistem Pendidikan Nasional.

Peraturan Pemerintah Nomor 17 Tahun 2010 tentang Pengelolaan dan Penyelenggaraan Pendidikan sebagaimana telah diubah dengan Peraturan Pemerintah Nomor 66 Tahun 2010.

Peraturan Menteri Pendidikan dan Kebudayaan Nomor 61 Tahun 2014 tentang Kegiatan Kurikulum Tingkat Satuan Pendidikan pada Pendidikan Dasar dan Menengah.

Peraturan Menteri Pendidikan dan Kebudayaan Nomor 62 Tahun 2014 tentang Kegiatan Ekstra Kurikuler pada Pendidikan Dasar dan Menengah.

Peraturan Menteri Pendidikan Nasional Nomor 34 Tahun 2006 tentang Pembinaan Prestasi Peserta Didik yang memiliki Potensi Kecerdasan dan/atau Bakat Istimewa.

Peraturan Menteri Pendidikan Nasional Nomor 19 Tahun 2007 tentang Standar Pengelolaan Pendidikan oleh Satuan Pendidikan Dasar dan Menengah.

Peraturan Menteri Pendidikan Nasional Nomor 39 Tahun 2008 tentang Pembinaan Kesiswaan.

Kesepakatan Bersama antara Menteri Negara Lingkungan Hidup dengan Menteri Pendidikan Nasional Nomor 03/MENLH/02/2010 dan Nomor 01/II/KB/2010 tentang Pendidikan Lingkungan Hidup.

Peraturan Menteri Lingkungan Hidup Nomor 05 Tahun 2013 tentang Pedoman Program Adiwiyata. Penampilan, Pelayanan, Prestasi Sekolah Menengah Atas, 2015, Dit. Pembinaan SMA

Maslow, Yogyakarta: Penerbit Kanisius.

Samani. Muchlas dan Hariyanto, 2011, “Konsep dan Model” PendidikanKarakter, Bandung: PT. Remaja Rosdakarya.

Koesoema. Doni A, 2010, Pendidikan Karakter: Strategi Mendidik Anak diZaman Global, Jakarta: Grasindo http://www.membumikanpendidikan.com/2015/03/strategi-pembangunan-karakterbangsa_10.html 